\title{
Investigation and simulation of flood inundation hazard in urban areas in Iran
}

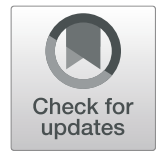

\author{
Mohammad Rostami Khalaj (D), Hamzeh Noor and Ali Dastranj
}

\begin{abstract}
Extensive impervious area and the man-made streams are the characteristics of urban areas. In recent years, rapid urbanization has led to change of rural areas into urban areas, and urban runoff will increase as the result of spread and growth of impervious areas. Land use changes, increasing urbanization, unauthorized construction, inefficiency of sewage system and increased impervious surface in urban areas have significant impacts on inundation hazard. Therefore, to manage urban areas and prioritize regions to inundation elimination problems, the area most affected by inundation should be determined. In this study, the Storm Water Management Model (SWMM) is used to simulate the rainfall-runoff in the study area. The simulated runoff in the SWMM model is used as input to the HECRAS model and determines inundation hazard zones in 5,25 and 50 return periods. Then, six factors such as distance from the main channel, slope, land use, drainage density, the main channel slope and elevation were selected to determine inundation hazard map using Analytic Hierarchy Process (AHP). The results showed that the combined model (SWMM and HEC-RAS) was suitable to analyze urban inundation and determine inundation hazard zones on urban areas. Simulated results can be used to develop urban inundation hazard forecasts. In addition, the result of inundation hazard map indicates that $8.2 \%$ of the case study is determined as a high hazard zone.
\end{abstract}

Keywords: Inundation, Urban runoff, SWMM model, Analytic hierarchy process

\section{Introduction}

Urbanized areas are accompanied by increase in impervious areas such as construction of drainage systems, roads, roofs, destruction of soils structure, and destruction of vegetation due to growth urban area (Hsu et al., 2000; Hung et al., 2018; Kamali et al., 2017; Shuster et al., 2005; Sillanpää \& Koivusalo, 2015). This results in increased water pollution, hydrocarbons, heavy metals, pathogens and nutrients (Phillips et al., 2018; Pitt and Jr, 2001; Qin et al., 2016). Complexities in the drainage infrastructures and urban areas have a natural influence on surface runoff that this runoff causes urban inundating (Chen et al., 2009; Jamali et al., 2018). Urban inundation due to any kind of inefficiency or defect of urban drainage systems causes considerable damage in

\footnotetext{
* Correspondence: m.rostamikhalaj@areeo.ac.ir

Soil Conservation and Watershed Management Research Department,

Khorasan Razavi Agricultural and Natural Resources Research and Education Center, AREEO, Mashhad, Iran
}

Springer Open buildings and other private and public infrastructure and is among destructive and the common natural hazards (Chen et al., 2018b; Hammond et al., 2015; Price \& Vojinovic, 2008; Tingsanchali, 2012). Moreover, urban inundation can completely hinder or limit the traffic systems function, and loss of communications and business opportunities is among its indirect consequences. Urban inundation hazard is associated with the physical characteristics of inundation such as extension of inundation, water level above street, volume of water flowing and its duration (Zhu et al., 2016).

In recent years, some researchers have attempted to establish a more accurate relationship between rainfall runoff and urban inundation (Bates et al., 2010; Lee, 2018; Li et al., 2009; Radice et al., 2017). Various hydrological and hydraulic models have significant contribution to achieve this goal such as MIKE FLOOD (Löwe et al., 2017), ESTRYTUFLOW (Fewtrell et al., 2011), BREZO (Adeogun et al., 2015), SWM (Yu et al., 2015)

(c) The Author(s). 2021 Open Access This article is licensed under a Creative Commons Attribution 4.0 International License, which permits use, sharing, adaptation, distribution and reproduction in any medium or format, as long as you give appropriate credit to the original author(s) and the source, provide a link to the Creative Commons licence, and indicate if changes were made. The images or other third party material in this article are included in the article's Creative Commons licence, unless indicated otherwise in a credit line to the material. If material is not included in the article's Creative Commons licence and your intended use is not permitted by statutory regulation or exceeds the permitted use, you will need to obtain permission directly from the copyright holder. To view a copy of this licence, visit http://creativecommons.org/licenses/by/4.0/. 
and InfoWorks ICM (Russo et al., 2015). Though, most of these models isn't free, which limits their application. The storm water management model (SWMM), is opensource model and powerful tool to urban drainage analysis, which was developed from 1969 to 1971 by the EPA (Rossman, 2004) has been used by researchers in various urban areas (A. H. Elliott \& Trowsdale, 2007; Rossman, 2010) and coupled with other models, such as LISFLOOD-FP (Wu et al., 2017) and BreZo (Burns et al., 2015), to simulate urban inundation (Babaei et al., 2018; Chen et al., 2018a; Elliott and Trowsdale, 2007). HECRAS is a tow-dimensional (2D) model that developed by Hydrologic Engineering Center (HEC) (Staff, 2008) is one of the most popular model can coupled with SWMM model. HEC-RAS can simulate both unsteady and steady state flow conditions, and it can be used to calculate inundation areas. HEC-Geo RAS (GIS-based) were also used for accurate optimization of the geometry characteristics for real visualization of flood areas. The HEC-RAS model is frequently used in a river flooding study (Adams III et al., 2018; Gao et al., 2018; Sleiman, 2018), but in the present study, we used and evaluated the HEC-RAS and HEC-Geo RAS extension of ArcGIS10.2 to simulate inundation extents in street and its surface drainage. This hydrological and hydraulic coupled models does not require specific knowledge, nor does it on any commercial modules. Developing hydrological and hydraulic models that provide accurate estimates of urban inundation hazards are important to describe the best strategies for inundation risk mitigation (Ballesteros et al., 2011; de Kok \& Grossmann, 2010).

In this study, we attempted that use qualitative and quantitative methods for urban inundation zone and urban inundation hazard, and provide remarkable information of the inundation depth to reduce environmental hazards of the areas at inundation risk.

The impact of inundation risk in urban areas may be very higher than rural area because the areas affected are contain vital infrastructure and densely populated. Rapid development increases this risk in flood prone areas (Deepak et al., 2020). Urban inundation hazard maps are valuable tools and help to planning the future direction of city growth. There are many factors that affect urban inundation hazard. Combination of various factors affecting inundation and determination of the priority of their importance require an in-depth study. Therefore, to obtain accurate results, we need a powerful method to consider all factors in terms of their importance and study of the relationships between factors.

Multi criteria decision analysis (MCDA) offers techniques and methodology to analyze decision problems, and it has been acknowledged as an important method in environmental decisions (Danumah et al., 2016). The use of MCDA and GIS has been proven successful in studies on natural hazards. Analytic Hierarchy Process (AHP) is one of the most generally used methods to solve MCDA (Sleiman, 2018) problems and is widely used for suitability analysis and natural hazard (Kokangül et al., 2017; Luu et al., 2018; Papaioannou et al., 2015).

The specific objectives of this study are to (1) calibrate and validate the SWMM model to urban rainfall-runoff simulation (2) assess the capability of integrating the SWMM model with the HECRAS model for inundation zone mapping (3) provide an urban inundation hazard mapping using AHP with GIS support. The importance of the study is to provide remarkable information of the inundation depth to reduce environmental hazards of the areas at inundation risk so that it can be given as an input for local planning and decreasing the risk to property, people and the environment.

Urban areas have been generally considered as a datascarce region due to the lack of hydrological gauges and hydraulic information. The novelty of this study lies in comparing the results of a hydrological model (Storm Water Management Model; SWMM) with a knowledgebased method (Analytic Hierarchy Process, AHP) that help decision-makers for urban flood management, especially in developing countries.

\section{Study site description}

Emam-Ali Town is situated in the western part of Mashhad city in Khorasan Razawi Province, between $36^{\circ} 22^{\prime}$ $20^{\prime \prime}$ to $36^{\circ} 23^{\prime} 1^{\prime \prime} \mathrm{N}$ latitudes, and $48^{\circ} 26^{\prime} 38^{\prime \prime}$ to $48^{\circ} 27^{\prime}$ $21^{\prime \prime}$ E longitudes (Fig. 1). It covers an area of approximately $82.3 \mathrm{ha}$. Mean annual precipitation is $250 \mathrm{~mm}$, the maximum and minimum temperature is $35^{\circ} \mathrm{C}$ and $15^{\circ} \mathrm{C}$ respectively. The surface elevation in Emam-Ali town varies from 1005 to $1014.61 \mathrm{~m}$ above sea level. The drainage system in study area for storm water is entirely an open drainage network and consists of concrete lined channels and open triangular channel in different dimension. The drainage system has a main channel running from southwest to northeast. Smaller dimensions channels are leading the water from the buildings, other residential houses to the main channel. The drainage water is further lead into river Kashaf Rood. Flood inundation have occurred due to insufficient capacity in the drainage system at low-lying areas in the Emam-Ali Town. Figure 1 shows an example of flood inundation on the 2011/11/06. This event is examples of how mindless urbanization and demographic changes lead to urban inundation.

\section{Materials and methods}

The method consists of hydrological and geometrical data collection, interpretation and analysis described as: 


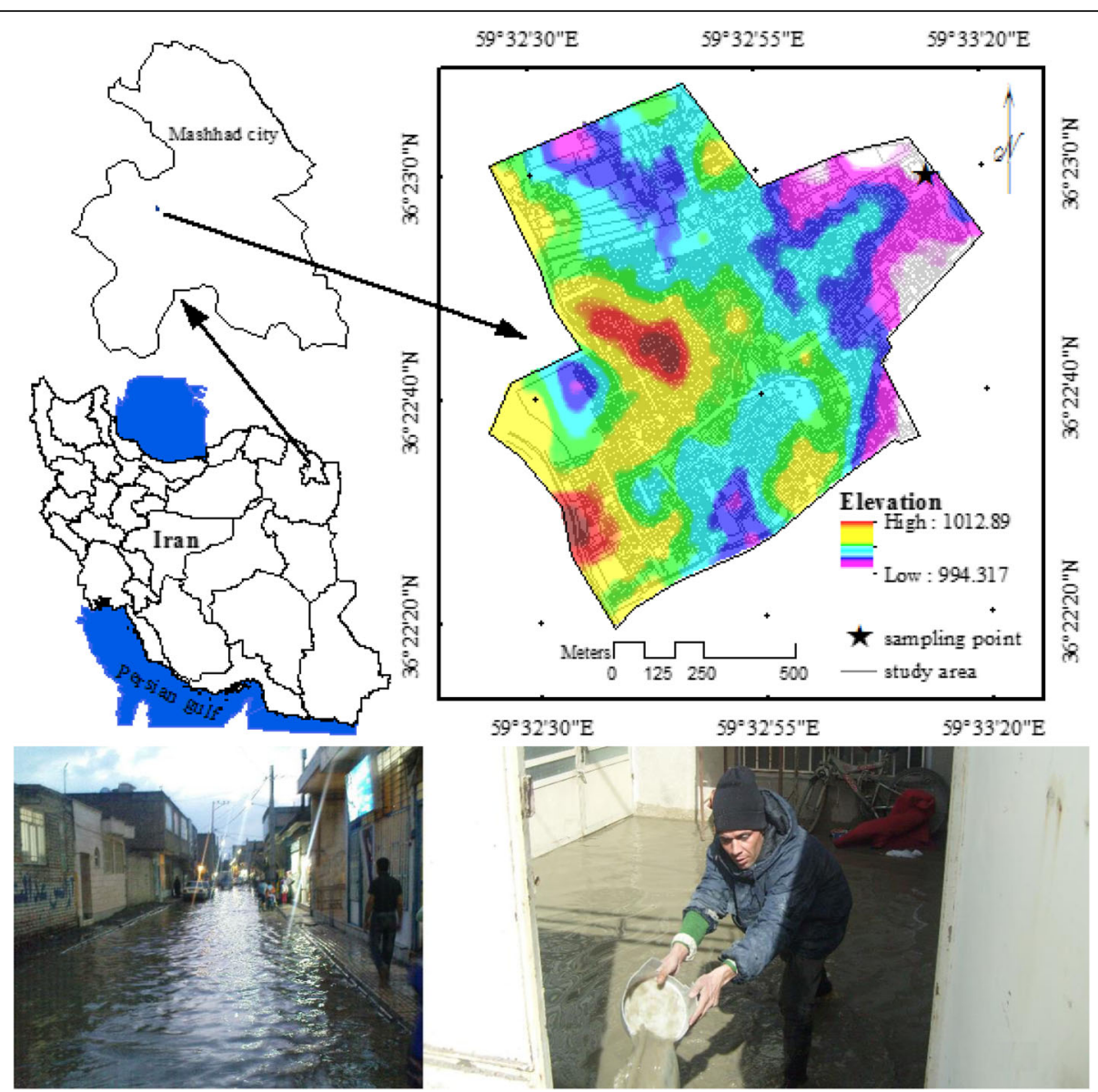

Fig. 1 Location of Emam-Ali Town in Mashhad city in Iran, and inundation in study area

- Rainfall runoff modeling using the SWMM.

- Inundation zone mapping using HEC-RAS

- Inundation hazard mapping using AHP

Figure 2 depicts the steps followed and the methods used in in this study.

\section{Rainfall runoff modeling using SWMM model}

SWMM is used to simulate the storm sewer flow component. To use the simulation models, it is necessary to estimate the model parameters relevant to the urban drainage system(Dayaratne \& Perera, 2004).

In SWMM, catchment is broken into a number of subcatchments(Elliott et al., 2010); therefore, all the subcatchments and the sewer-networks of the catchment area were located on the map. As a result, 61 subcatchments in the study area were identified.

In this case, eight parameters were selected for calibration these parameters are listed in Table 1 . The values of percent of impervious area (\%Imperv), width of overland flow (Width) and slope were different in the various subcatchments and can be measured in GIS based on the Digital Elevation Model (DEM) data (pixel size $30 \mathrm{~m}$ ), land use maps and subcatchment areas. For model calibration the values of these three parameters were increased or decreased simultaneously. In Table 1, the percentage change scales for these three parameters are mentioned. In this study, the trial-and-error method was used to calibrate the hydrologic model (Dongquan et al. 2009).Calibration is a time-consuming task so to improve calibration yield the number of parameters used to calibration process should be kept to a minimum(Dongquan et al., 2009). In this study, lumped parameters were used to reduce the numbers of calibration parameters. In lumped parameter each subcatchment had only one value for each parameter. Therefore, other parameters such as Mannings $\mathrm{N}$ for impervious area ( $\mathrm{N}$-imperv), Mannings $\mathrm{N}$ for pervious area (N-perv), depth of depression storage on impervious area (Des-imperv), depth of depression storage on pervious area (Des-perv) and percent of impervious area with no depression storage (Zero-Imperv) were assumed to be lumped. The initial values of the parameters that are not directly measurable were determined by the SWMM user's manual(Rossman, 2010) and literature references(Tsihrintzis and Hamid 1998; Dongquan et al. 2009). The initial values of the parameters are listed in Table 1. 


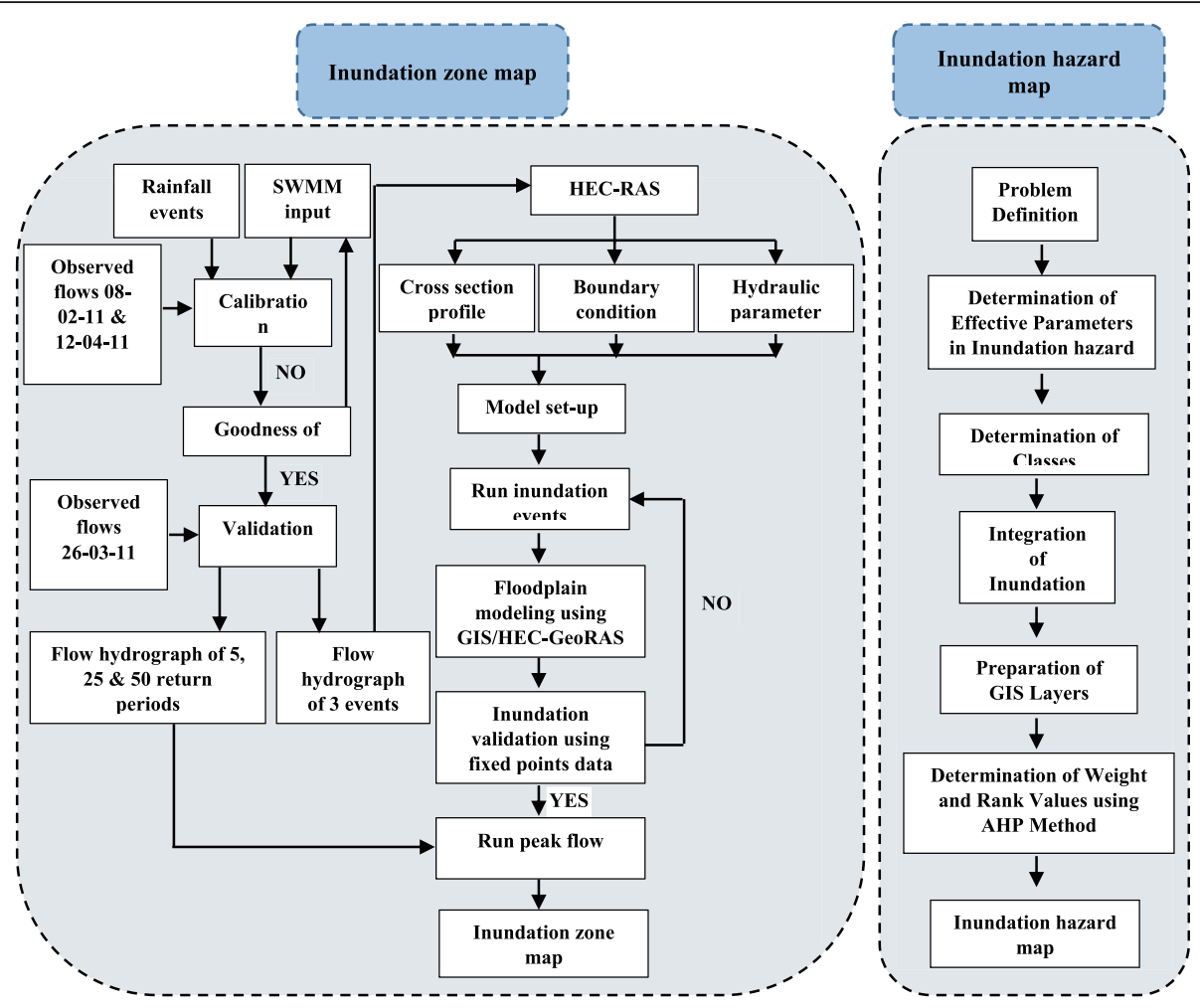

Fig. 2 Methodology flowchart of inundation zone and hazard mapping

The infiltration parameters, the roughness coefficients, and the depression storage can be estimated from empirical values; therefore, in the calibration procedure, they must be considered (Chen et al., 2018b; Dongquan et al., 2009; Du et al., 2007; Wu et al., 2018; Wu et al., 2017).

Three rainfall events occurred during the study. The rainfall events of 08-02-2011 and 12-04-2011 were used for the calibration, and the rainfall event of 26-03-2011 was used for validation. Rain-depth data in $(\mathrm{mm})$ were measured from the rain gauge at near of the study area. Flow was measured at the outlet of the catchment for these three events.

The use of mathematical models requires the estimation of model parameters, which is usually known as the calibration of the model(Dayaratne \& Perera, 2004). No

Table 1 SWMM model calibration parameters

\begin{tabular}{llll}
\hline Parameters & Rank of variation allowed & Initial value & Optimal value \\
\hline Imperv (\%) & $\pm 30 \%^{\mathrm{a}}$ & - & - \\
Slope (\%) & $\pm 30 \%^{\mathrm{a}}$ & - & - \\
Width (m) & $\pm 30 \%^{\mathrm{a}}$ & - & - \\
N-imperv & $0.011-0.033^{\mathrm{b}}$ & 0.013 & 0.018 \\
N-perv & $0.02-0.8^{\mathrm{a}}$ & 0.05 & 0.02 \\
Des-imperv (mm) & $0.3-2.5^{\mathrm{b}}$ & 1.778 & 2 \\
Des-perv (mm) & $2.5-5.1^{\mathrm{c}}$ & 3.81 & 4.1 \\
Zero-Imperv (\%) & $5-20^{\mathrm{b}}$ & 21 & 18 \\
\hline
\end{tabular}

a (Temprano et al., 2005)

b (Rossman, 2010)

c (Tsihrintzis \& Hamid, 1998)

- Without optimal value and a single initial value (distributed parameter)

Percent of impervious area (\%lmperv), Width of overland flow (Width), Mannings $\mathrm{N}$ for impervious area (N-imperv), Mannings $\mathrm{N}$ for pervious area (N-perv), Depth of depression storage on impervious area (Des-imperv), Depth of depression storage on pervious area (Des-perv) and Percent of impervious area with no depression storage (Zero-Imperv) 


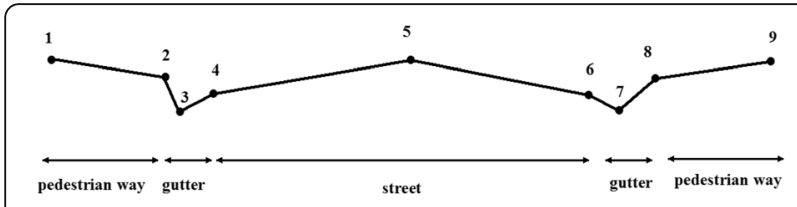

Fig. 3 A typical profile of cross sections

matter how good and precise the model is, it can never describe the complete complexity of nature. By performing a calibration of the model, it can become closer to describing the behavior of nature, sometimes resulting in a useful model(Reuterwall \& Thorén, 2009).

To see if the calibration is successful, an independent period of rainfall and water level measurements in the area should be tested in the model. If the output result of this period yields the same satisfying result in the calibration, the model calibration can be assumed successful. If the validation yields a very poor result, it might be necessary to redo the calibration. The most popular likelihood function is the Nash-Sutcliffe coefficient of efficiency (NS) (Nash \& Sutcliffe, 1970) and Root mean square error (RMSE) as given by eqs. 1 and 2 used to calibrate and validate the model.

$$
\begin{gathered}
\mathrm{NS}=1-\frac{\sum_{\mathrm{i}=1}^{\mathrm{n}}\left(\mathrm{Q}_{\mathrm{i}}^{\text {sim }}-\mathrm{Q}_{\mathrm{i}}^{\text {obs }}\right)^{2}}{\sum_{\mathrm{i}=1}^{\mathrm{n}}\left(\mathrm{Q}_{\mathrm{i}}^{\text {obs }}-\mathrm{Q}^{\text {av }}\right)^{2}} \\
\text { RMSE }=\sqrt{\frac{1}{\mathrm{n}} \sum_{\mathrm{i}=1}^{\mathrm{n}}\left(\mathrm{Q}_{\mathrm{i}}^{\text {sim }}-\mathrm{Q}_{\mathrm{i}}^{\text {obs }}\right)^{2}}
\end{gathered}
$$

where $\mathrm{Q}_{\mathrm{i}}^{\text {sim }}=$ simulated discharge at time $i, \mathrm{Q}_{\mathrm{i}}{ }^{\text {obs }}=\mathrm{ob}$ served discharge at time $i, \mathrm{Q}^{\text {av }}=$ average of the observed discharge, and $n=$ the number of time steps in the calibration period. Root mean square error (RMSE) is also used as an objective function in the model calibration and validation as given in Eq. 2 .

Table 2 Saaty's scale weight assignment and it's interpretation (Saaty, 1980)

\begin{tabular}{ll}
\hline Weight & Definition \\
\hline 1 & Equal \\
2 & Equal to moderate \\
3 & Moderate \\
4 & Moderate to strong \\
5 & Strong \\
6 & Strong to very strong \\
7 & Very strong \\
8 & Very strong to extreme \\
9 & Extreme \\
\hline
\end{tabular}

Table 3 Random inconsistency indices (Saaty, 1980)

\begin{tabular}{lllllllllll}
\hline $\mathbf{N}$ & $\mathbf{1}$ & $\mathbf{2}$ & $\mathbf{3}$ & $\mathbf{4}$ & $\mathbf{5}$ & $\mathbf{6}$ & $\mathbf{7}$ & $\mathbf{8}$ & $\mathbf{9}$ & $\mathbf{1 0}$ \\
\hline $\mathrm{Rl}$ & 0.00 & 0.00 & 0.58 & 0.90 & 1.12 & 1.24 & 1.32 & 1.41 & 1.46 & 1.49 \\
\hline
\end{tabular}

\section{Inundation zone mapping using HEC-RAS model}

An inundation zone map based on water depth and its probability demonstrates the area categories of hazard levels. In this study, hydraulic and hydrological methods are used to obtain the inundation zone map of EmamAli Town. Inundation zone maps were produced using 2D hydraulic model of HEC-RAS and HEC-GeoRAS extension of ArcGIS10.2.

Generally, the HEC-RAS model is used to define the water level profile in river, but in this study, in new application, the main streets and the gutters on both sides were considered as river, and the pedestrian ways were considered as bank of river. Additionally, the pedestrian ways and street reaching the main street were considered as secondary river.

Several RAS themes were created with HEC-GeoRAS preprocessing such as stream flow path centerline, centerline, bank line, storage area, land use area and crosssectional cutlines connections in ArcGIS format. TIN with these themes were used to develop the geometric data. The cross sections elevation data (geometric data) are obtained using field survey data by 'Leica TS 09'.

Approximately 280 cross sections profiles were taken in the studied area. A typical profile shown in Fig. 3 contained 9 points, including the foot of both side walls (points 1 and 9), both pedestrian ways (points 2 and 8 ), both gutters (points 3, 4,6, and 7) and the midpoint of the street section (point 5).

In a steady state, HEC-RAS computes water surface elevation (WSE) and velocity at discrete cross-sections by solving continuity, energy and flow resistance (e.g., Manning) equation.

We assumed mixed flow for flow through the street (street as river). HEC-RAS computes velocity and water surface elevation at the cross sections using solving continuity flow resistance and energy equation such as Manning equation. The flow data for the different return period are imported from SWMM. The HEC-RAS model is run and inundation zone along the street is computed. In HEC-GeoRAS, GIS layers for inundation zone and inundation depth are created.

To validate the HEC-RES model, inundation depth was measured at ten fixed points at half an hour intervals in three rainfall events occurred during the study. This inundation depth was used as observation inundation depth, and the HEC-RAS model is run with runoff obtained from the SWMM model simulation for tree rainfall events. Finally, observation inundation depth was compared to the inundation depth that simulated the 


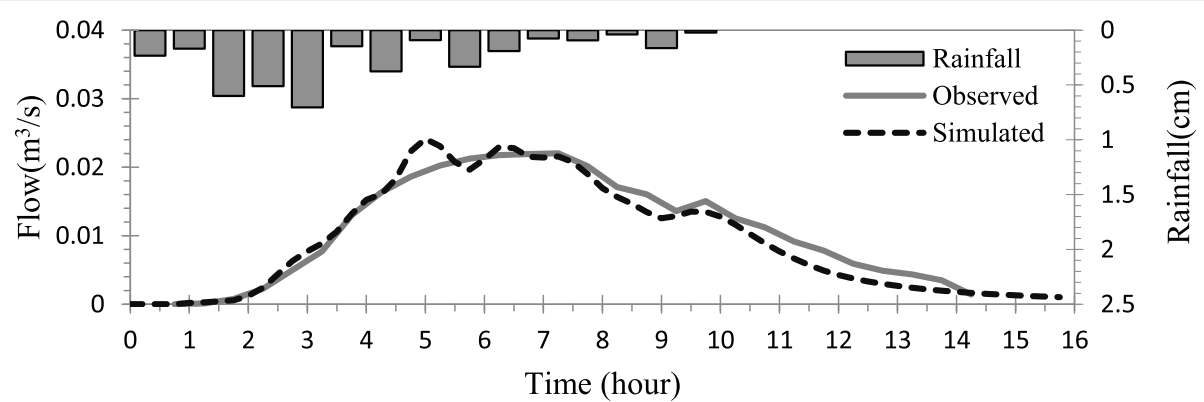

Fig. 4 Comparison of simulated and observed hydrographs derived from calibration, run for the rainfall event of 08-02-2011

HEC-RES model. Root mean square error (RMSE) was used as an objective function for HEC-RES model validation. If provided inundation map had enough accurate, inundation zoning map is provided for different return periods.

\section{Inundation hazard mapping}

An inundation hazard map indicates the area at inundation risk and defines the areas in danger where the inundation events are probable to occur. Inundation hazard mapping is so important for urban risk management and land use planning (Thirumurugan \& Krishnaveni, 2019). The six different factors considered in the study are distance to the main channels, slope, the drainage density, the elevation layer, land use layers and the main channel slope. The variables were selected based on the quality of the data that were existing and their relevance with the inundation sensitivity of the study area. Analytic Hierarchy Process (AHP) (Saaty, 1980) was used to assign weight to the layers and rank values to the classes of each layer.

The following steps are taken using the AHP method to calculate the weights for the different criteria: (1) Creating a pairwise comparison matrix. AHP is a multicriteria and multi-objective decision making approach that uses a pair-wise comparison process to attain a scale of preferences among a set of alternatives (Fernández \& Lutz, 2010). This uses a basic scale of numbers to definite individual judgments or preferences. This scale is based on a scale of 1-9, and pair-wise judgments are made according to experience, knowledge and available information (Table 2).

(2) Creating the normalized pairwise comparison matrix.

(3) Calculating the weights of criteria.

(4) Calculating the Consistency Ratio (CR) (Eq. 1).

$$
C R=\frac{C I}{R I}
$$

That: RI is a Random Inconsistency Index that is obtained from Table 3. CI is Consistency Index. It is calculated by Eq. 2:

$$
C I=\frac{\lambda_{\max }-n}{n-1}
$$

That: $\mathrm{n}$ is the number of options in the decision matrix (order of the matrix), and $\lambda_{\max }$ is the maximum eigenvalue and calculated by averaging the value of the consistency vector.

\section{Results}

\section{Rainfall-runoff simulation}

The SWMM model was run using the initial eight parameter. These parameters were the impervious fraction, slope, the subcatchment width, the depression storage of the impervious and pervious areas, the percent of the

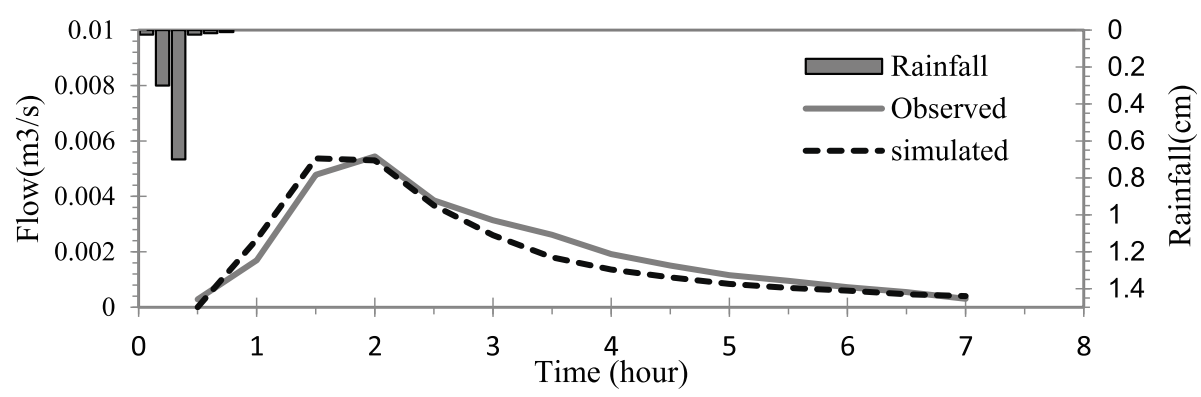

Fig. 5 Comparison of simulated and observed hydrographs derived from calibration, run for the rainfall event of 12-04-2011 


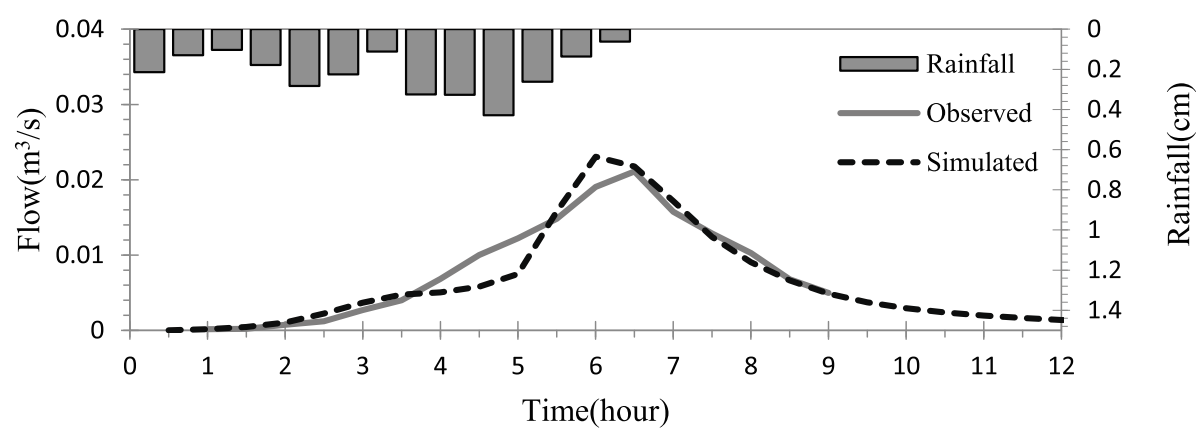

Fig. 6 Comparison of simulated and observed hydrographs derived from validation, run for the rainfall event of 26-03-2011

impervious area with no depression storage, the Manning's roughness for the impervious and pervious areas. These parameters was optimized in the calibration performance using a trial-and-error procedure. Rainfallrunoff simulation was conducted for the three rainfall events calculating the optimum hydrological model parameters using the indices given in Nash-Sutcliffe coefficient of efficiency and the simulated result was compared with the observed data at the outlet. Figures 4 and 5 show the comparison of the observed and simulated hydrographs for a calibrated event. As the figures show, there is a good agreement between the two series.

The values of some input parameters are estimated for initial run of the model, that after model calibration, the optimal values are obtained for the model inputs. Table1 presents the ranges of calibrated parameters and optimal parameters. The parameters of hydraulic adjustment, obtained in the calibration process, were used with an independent rain concomitantly (rainfall event of 26-032011) for model validation, and the results are shown in Fig. 6.

Table 4 shows the values of NS and RMSE for the validated event. The lower RMSE values and the NS values higher than 0.5 , indicate that the calibrated model acceptably simulates the shape of actual hydrographs and supports the accuracy of the calibrated model (Dongquan et al., 2009; Engel et al., 2007).

\section{Inundation zone map}

After confirming the SWMM model in calibration and evaluation steps, the HEC-RAS model was calibrated and validated at ten fixed points where inundation depth was measured during three event. Table 5 shows the

Table 4 Calibration and validation performance

\begin{tabular}{llll}
\hline process & date & NS & RMSE \\
\hline calibration & $08-02-2011$ & 0.938 & 0.00179 \\
& $12-04-2011$ & 0.92 & 0.00043 \\
validation & $26-03-2011$ & 0.84 & 0.0026 \\
\hline
\end{tabular}

values of RMSE for the HEC-RAS validation. The values of RMSE for maximum inundation depth show that the model illustrated an acceptable response to the tree inundation event and the optimized parameters were considered suitable for modeling.

The scatter plot show that the under prediction of inundation depth by HEC-HRS model for the three events in which the simulated inundation depth values are mostly distributed on the lower side of the 1:1 line as shown in Fig. 7. The HEC-RAS model was found to simulate inundation depth with an acceptable level of accuracy. The values of R2 during the simulation period were obtained $0.87,0.96$ and 0.94 for three events, respectively.

The SWMM model was run for 5, 25 and 50 rainfall return periods, and output runoff was used as input to the HEC-RAS model, and inundation zone map is provided for different return periods. The results also revealed a significant increase in inundation extent in different return periods. From Figs. 8, 9 and 10 shows the inundation zone map and water depth at selected cross sections profiles in different return periods. In a 5 -year return period, the depth of inundation in center of street would be approximately, $1.5 \mathrm{~cm}$ to $8 \mathrm{~cm}$ at cross sections profiles, $2 \mathrm{~cm}$ to $10 \mathrm{~cm}$ in a 25 -year return period and $5 \mathrm{~cm}$ to $15 \mathrm{~cm}$ in a 50 -year, return period. The result of inundation zone map and water depth at cross sections profiles showed the inundation depth at the outlet of study area is higher than the other area.

\section{Inundation hazard map}

The inundation hazard map was divided into four classes as: areas with low hazard, areas with moderate hazard, areas with high hazard and areas with very high hazard (Fig. 11). The interval between each classes were evaluated based on expert judgment, according to the frequency histogram. As Fig. 11 shows, the areas adjacent to outlet the study area were characterized as a very high inundation hazard $(8.2 \%)$ owing to the combination of runoff concentration in this area with decrease slope of the main channel and the presence of stream channels 
Table 5 The Observed and Simulated depth for the HEC-RAS validation

\begin{tabular}{|c|c|c|c|c|c|c|}
\hline \multirow{2}{*}{$\begin{array}{l}\text { Sampling } \\
\text { points }\end{array}$} & \multicolumn{2}{|l|}{ Event 08-02-2011 } & \multicolumn{2}{|l|}{ Event 26-03-2011 } & \multicolumn{2}{|l|}{ Event 12-04-2011 } \\
\hline & $\begin{array}{l}\text { Observed depth } \\
\text { (m) }\end{array}$ & $\begin{array}{l}\text { Simulated depth } \\
\text { (m) }\end{array}$ & $\begin{array}{l}\text { Observed depth } \\
\text { (m) }\end{array}$ & $\begin{array}{l}\text { Simulated depth } \\
\text { (m) }\end{array}$ & $\begin{array}{l}\text { Observed depth } \\
\text { (m) }\end{array}$ & $\begin{array}{l}\text { Simulated depth } \\
\text { (m) }\end{array}$ \\
\hline 1 & 0.04 & 0.027 & 0.06 & 0.0452 & 0.05 & 0.0344 \\
\hline 2 & 0.04 & 0.0565 & 0.04 & 0.0525 & 0.04 & 0.0357 \\
\hline 3 & 0.06 & 0.0537 & 0.07 & 0.0507 & 0.045 & 0.0277 \\
\hline 4 & 0.08 & 0.0733 & 0.085 & 0.0712 & 0.07 & 0.0502 \\
\hline 5 & 0.04 & 0.0548 & 0.07 & 0.0538 & 0.05 & 0.0312 \\
\hline 6 & 0.05 & 0.0343 & 0.045 & 0.0333 & 0.02 & 0.0051 \\
\hline 7 & 0.07 & 0.0563 & 0.07 & 0.0545 & 0.04 & 0.0252 \\
\hline 8 & 0.07 & 0.0559 & 0.06 & 0.054 & 0.03 & 0.0195 \\
\hline 9 & 0.15 & 0.1605 & 0.17 & 0.152 & 0.11 & 0.094 \\
\hline 10 & 0.11 & 0.09265 & 0.1 & 0.0884 & 0.04 & 0.028 \\
\hline RMSE & 0.013381 & & 0.01426 & & 0.01497 & \\
\hline
\end{tabular}

with poor maintenance plan. In these areas there are commercial and educational land uses that could be an increasing inundation hazard. Another factor that which can be seen in this area is the change in local topography and unfinished civil structure that is could be an increasing inundation hazard.

In the area with very high inundation hazard, several inundation records have been reported by the Emam-Ali Town authority and residents of the area. Moreover, the results of inundation zone map confirm that inundation depth has increased in the areas adjacent to outlet the study area.

\section{Discussion}

Flood inundation is one of the important natural hazard affecting developed countries through the world (Erena \& Worku, 2018). One of the approaches to reduce and prevent losses is to provide information about flood inundation risk and hazard through a inundation map (Aitsi-Selmi et al., 2016; Zin et al., 2018). The urban hydrological model could not handle a large quantity of distributed data, so simplification of the model and parameters should be regarded. Urban runoff is one of the factors having the highest effect on storm sewers design and storm water management. Solving storm sewer flows usually needs utilizing the SWMM model to provide the surcharged flow hydrographs for surface runoff exceeding the capacity of the storm sewers. Due to the capabilities of the SWMM model in estimating runoff and providing output in each junction, it can be concluded that the SWMM model has an acceptable flexibility to combine with other models (Dongquan et al., 2009), and the simulated hydrograph in each junction is used as input for other models (Lin et al., 2006).
Among the eight parameters were used for calibration, the impervious fraction (\%Imperv) is the key sensitive parameter, showing a strong effect on the peak flows and the total volume of runoff (Chen et al., 2018b; Temprano et al., 2005; Xing et al., 2016). Therefore land use change and urbanization that increase the amount of impervious areas causes increases peak flows and inundation hazard in study area (Sarhadi et al., 2012; Wahren et al., 2009). The percentage of impervious fraction and width was close to the initial measured value, presenting a considerable influence on the total volume of runoff and the peak flows. However, slope, width and the Manning's roughness coefficient affected the time of concentration of peak flows (Dongquan et al., 2009).

The results of calibration and validation of the SWMM model showed a considerable adaptation between simulated and observed runoff. The obtained results could be used to design, manage and operate various water resource vicissitudes. It also implies on-going evolution of the SWMM package to provide storm water management needs with appropriate answers (Zoppou, 2001). In addition, the results obtained in the calibration process can be used to estimate the optimal parameter value and this optimal parameter can be used in other areas similar to the study area (Choi \& Ball, 2002).

The developed inundation hazard map and inundation zone map includes information about depth and inundation area also information structures such as public buildings, hospitals, schools and roads (Zin et al., 2018). This information can be applied for urban management purposed in order to select technique in relation to the flood inundation area and proposed flood inundation protection measures (George Papaioannou et al., 2018). A major limitation of the present work is that the HECRAS model does not have the ability to simulate flood 

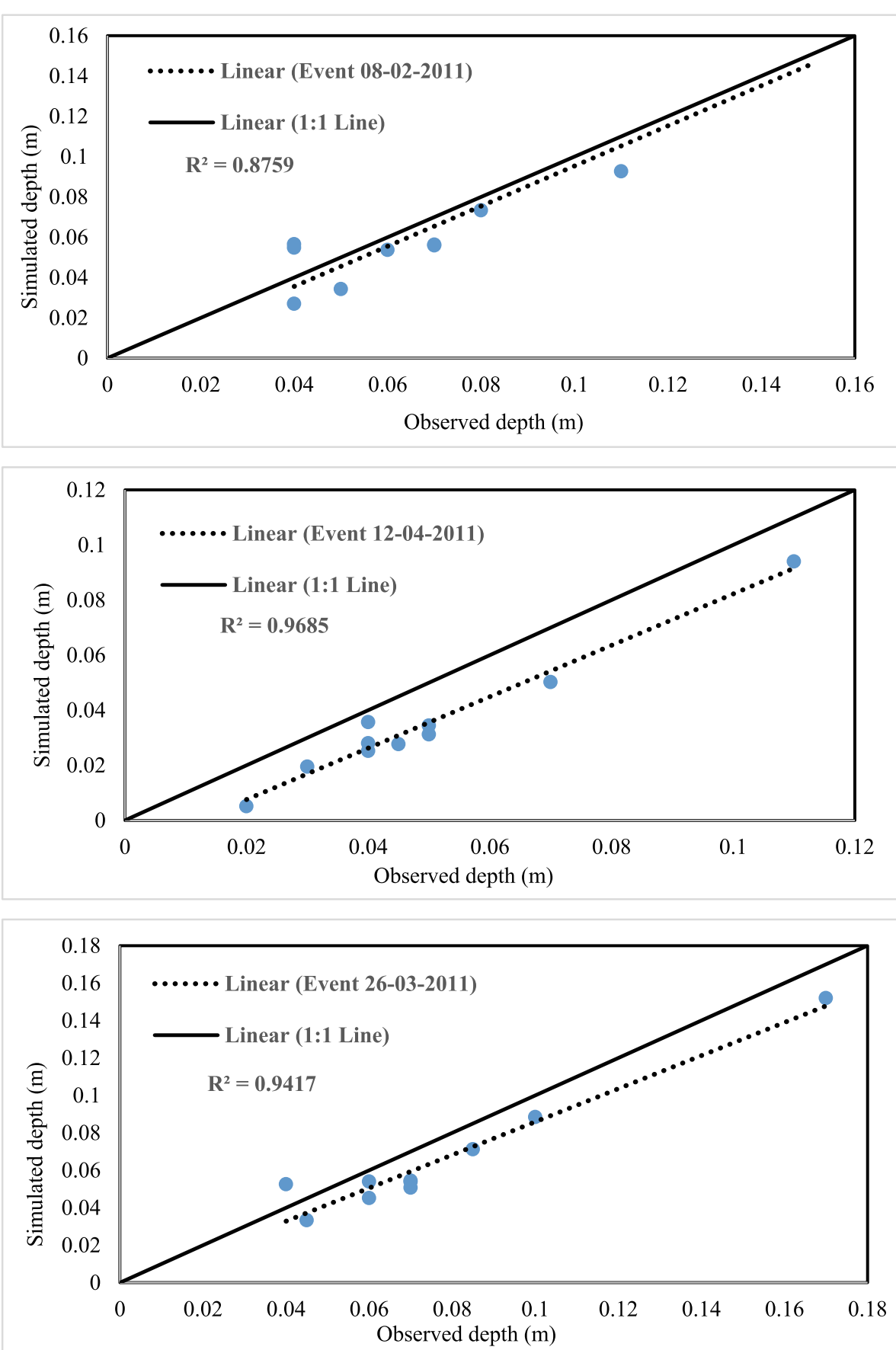

Fig. 7 Scatter plot of observed inundation depth versus simulated inundation depth by HEC-RAS

inundation from the subsurface drainage systems in study area.

The results of the AHP model indicated that distance to the main channels (weight $=0.422$ ), slope (weight $=0.278$ ), and slope of the main channel (weight $=0.135$ ) were the most important factors. In Fernández and Lutz (2010) study, distance to the main channels was the most important layer in inundation hazard mapping, a finding confirmed in the present study. Inundation hazard increased in the slope blow $3 \%$, in fact, in very flat area (slope $<3 \%$ ) where ponding happens, a remarkable amount of surface runoff may be retained, resulting in inundation. A major disadvantage of the AHP method is based on expert judgment, which results can be sensitive to weights that selected by expert and results have higher uncertainty (Chan et al., 2000; Fernández \& Lutz, 2010). 


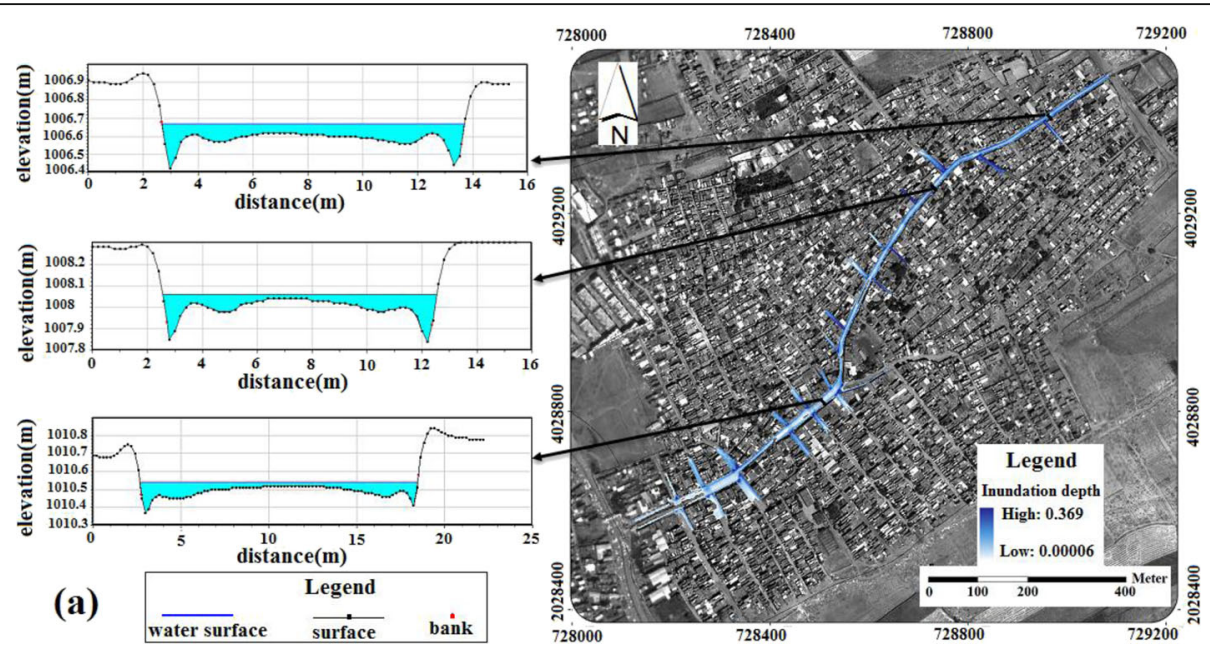

Fig. 8 Inundation zone map and water depth at cross sections profiles in 5 year return period

\section{Conclusion}

One of the most important tasks of management is decision-making, and the most important element of decision-making is to provide appropriate information. Information that can better reflect the future will lead to better decision-making. Inundation hazard mapping is one of the tools of urban management. The simple method used in this study identifies the areas more affected during inundation events. This method has good ability to manage flood inundation before the flood occurrence, crisis management and rescue during flood events.

The inundation zone map and water depth at cross sections profiles (Figs. 7, 8 and 9) were prepared in this study using the HEC-RAS model, and the evaluation results of this model showed that this model could be used for inundation zoning in the study area, map the areas in inundation hazard and manage urban basins to reduce the risks of urban inundation. The inundation zone map showed that storm water drainage system in the study area had less inundation problem in the 5-year return period, but in 25 and 50-year return has severe inundation problem in most parts of the region, and the storm water drainage system lost its efficiency; this result is confirmed by questioning and interviewing with residents of the area and the result was approved. With the expansion of cities in recent decades, the problem of inundation in the future is a major issue for the authorities of the region. The present study results indicated that by integrating hydrological (SWMM) and hydrologic (HECRAS) models with the aid of GIS, the inundation zone map could be prepared with considerable accuracy.

Inundation hazard map are indispensable tools for anticipating inundation magnitude and probable damages. This study presented an AHP model to map flood prone areas in the Emam-Ali Town in Khorasan Razavi

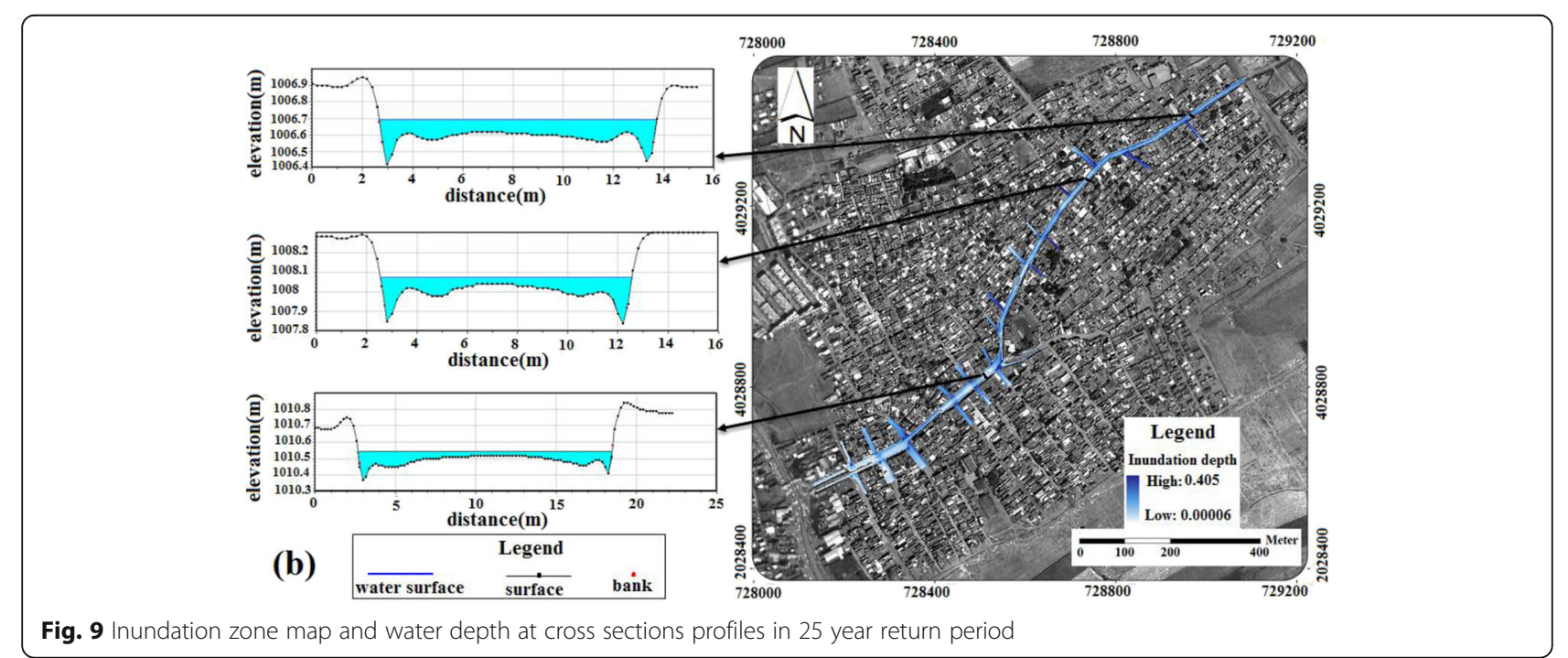



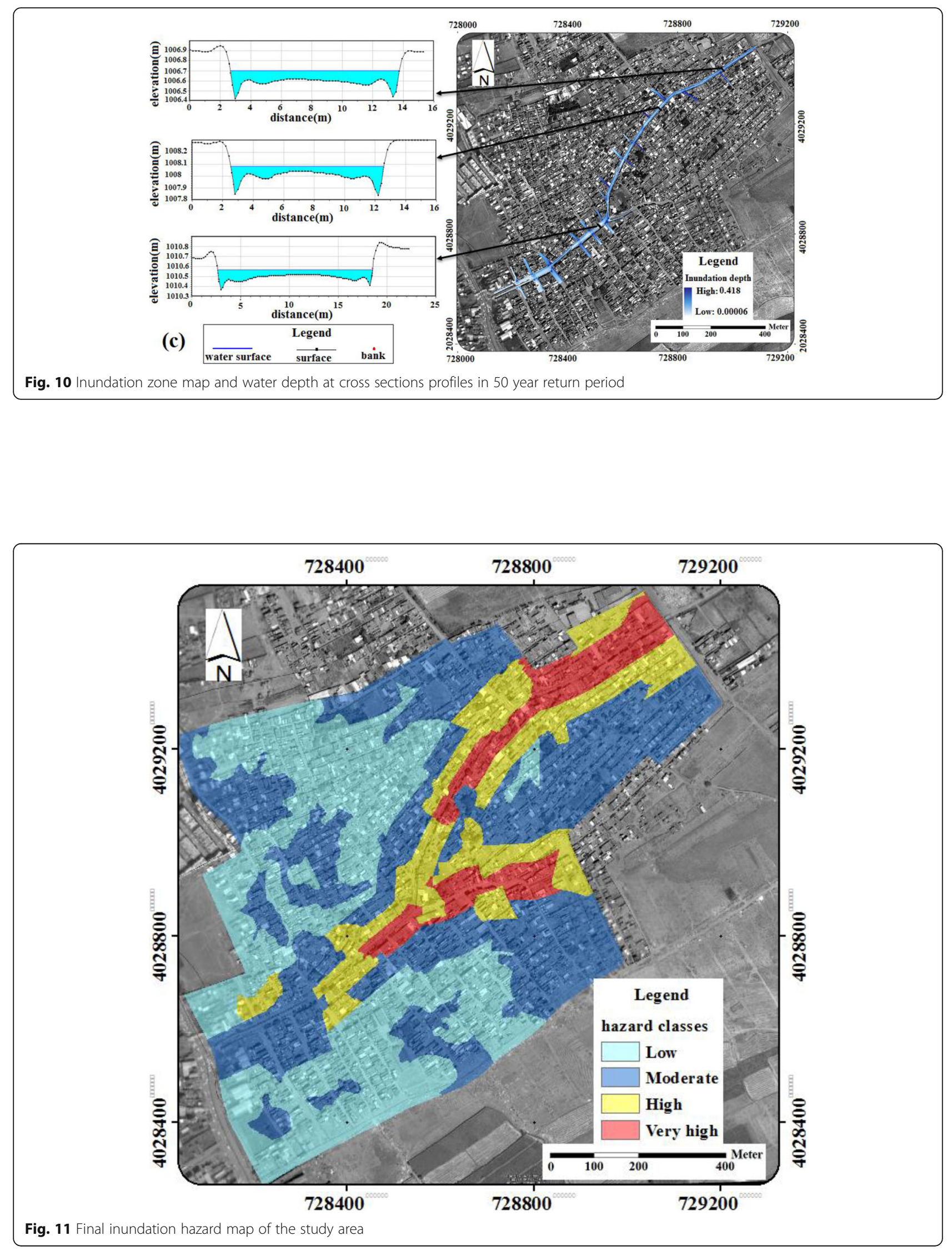
Province, Iran. Inundation inventory map and thematic layers of six inundation conditioning factors- distance to the main channels, slope, the drainage density, the elevation layer, land use layers and the main channel slope. Our result indicated that the distance to the main channels is the most important inundation conditioning factor in the study area. The coupled GIS-AHP method was found to be very effective in identifying susceptible areas to inundation. Application of this method is highly recommended, particularly in data-scarce areas with limited information about inundation characteristics such as inundation depth. Immediate inundation mitigation actions need to be urgently implemented in the study area, given that a large population lives in the study area.

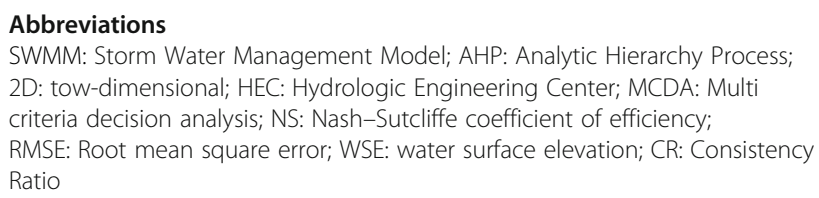

\section{Acknowledgments}

The authors would like to express their sincere thanks to Mashhad city authority for providing necessary data and maps.

\section{Authors' contributions}

The author is responsible for data collection, project planning and execution. The author read and approved the final manuscript.

\section{Funding}

The Funding came directly from the Mashhad Municipality.

\section{Availability of data and materials}

The data that support the findings of this study are available from [Khorasan Razavi Province, Mashhad Municipality] but restrictions apply to the availability of these data, which were used under license for the current study, and so are not publicly available. Data are however available from the authors upon reasonable request and with permission of [Khorasan Razavi Governorate].

\section{Declarations}

\section{Competing interests}

The author declares that he has no competing interests.

Received: 9 August 2020 Accepted: 1 July 2021

Published online: 09 August 2021

\section{References}

Adams TE III, Chen S, Dymond R (2018) Results from operational hydrologic forecasts using the NOAA/NWS OHRFC Ohio River community HEC-RAS model. J Hydrol Eng 23(7):4018028. https://doi.org/10.1061/(ASCE)HE.19435584.0001663

Adeogun AG, Daramola MO, Pathirana A (2015) Coupled 1D-2D hydrodynamic inundation model for sewer overflow: influence of modeling parameters. Water Sci 29(2):146-155. https://doi.org/10.1016/j.wsj.2015.12.001

Aitsi-Selmi A, Murray V, Wannous C, Dickinson C, Johnston D, Kawasaki A, Stevance A-S, Yeung T (2016) Reflections on a science and technology agenda for 21 st century disaster risk reduction. Int J Disaster Risk Sci 7(1):129. https://doi.org/10.1007/s13753-016-0081-x

Babaei S, Ghazavi R, Erfanian M (2018) Urban flood simulation and prioritization of critical urban sub-catchments using SWMM model and PROMETHEE ॥ approach. Phys Chem Earth, Parts A/B/C 105:3-11. https://doi.org/10.1016/J. PCE.2018.02.002

Ballesteros JA, Bodoque JM, Díez-Herrero A, Sanchez-Silva M, Stoffel M (2011) Calibration of floodplain roughness and estimation of flood discharge based on tree-ring evidence and hydraulic modelling. J Hydrol 403(1-2):103-115. https://doi.org/10.1016/j.jhydrol.2011.03.045

Bates PD, Horritt MS, Fewtrell TJ (2010) A simple inertial formulation of the shallow water equations for efficient two-dimensional flood inundation modelling. J Hydrol 387(1-2):33-45. https://doi.org/10.1016/j.jhydrol.2010.03. 027

Burns M, Schubert J., ... T. F.-W. I., \& 2015, undefined (2015) Testing the impact of at-source stormwater management on urban flooding through a coupling of network and overland flow models. Wiley Online Library 2(4):291-300. https://doi.org/10.1002/wat2.1078

Chan FTS, Chan MH, Tang NKH (2000) Evaluation methodologies for technology selection. J Mater Process Technol 107(1-3):330-337. https://doi.org/10.1016/ S0924-0136(00)00679-8

Chen J, Hill AA, Urbano LD (2009) A GIS-based model for urban flood inundation. J Hydrol 373(1-2):184-192. https://doi.org/10.1016/j.jhydrol.2009.04.021

Chen L, Dai Y, Zhi X, Xie H, Shen Z (2018a) Quantifying nonpoint source emissions and their water quality responses in a complex catchment: a case study of a typical urban-rural mixed catchment. J Hydrol 559:110-121. https://doi.org/10.1016/J.JHYDROL.2018.02.034

Chen W, Huang G, Zhang H, Wang W (2018b) Urban inundation response to rainstorm patterns with a coupled hydrodynamic model: a case study in Haidian Island, China. J Hydrol 564:1022-1035. https://doi.org/10.1016/j. jhydrol.2018.07.069

Choi K, Ball JE (2002) Parameter estimation for urban runoff modelling. Urban Water 4(1):31-41. https://doi.org/10.1016/S1462-0758(01)00072-3

Danumah JH, Odai SN, Saley BM, Szarzynski J, Thiel M, Kwaku A, Kouame FK, Akpa LY (2016) Flood risk assessment and mapping in Abidjan district using multicriteria analysis (AHP) model and geoinformation techniques, (cote d'ivoire). Geoenvironmental Disasters 3(1). https:/doi.org/10.1186/s40677-016-0044-y

Dayaratne S, Perera B (2004) Calibration of urban stormwater drainage models using hydrograph modelling. Urban Water J 1(4):283-297. https://doi.org/10.1 080/15730620412331299057

de Kok J-L, Grossmann M (2010) Large-scale assessment of flood risk and the effects of mitigation measures along the Elbe River. Nat Hazards 52(1):143166. https://doi.org/10.1007/s11069-009-9363-6

Deepak S, Rajan G, Jairaj PG (2020) Geospatial approach for assessment of vulnerability to flood in local self governments. Geoenvironmental Disasters 7(1). https://doi.org/10.1186/s40677-020-00172-w

Dongquan Z, Jining C, Haozheng W, Qingyuan T, Shangbing C, Zheng S (2009) GIS-based urban rainfall-runoff modeling using an automatic catchmentdiscretization approach: a case study in Macau. Environ Earth Sci 59(2):465472. https://doi.org/10.1007/s12665-009-0045-1

Du J, Xie S, Xu Y, Xu, C. yu, \& Singh, V. P. (2007) Development and testing of a simple physically-based distributed rainfall-runoff model for storm runoff simulation in humid forested basins. J Hydrol 336(3-4):334-346. https://doi. org/10.1016/.jhydrol.2007.01.015

Elliott AH, Trowsdale SA (2007) A review of models for low impact urban stormwater drainage. Environ Model Softw 22(3):394-405. https://doi.org/10.1 016/j.envsoft.2005.12.005

Elliott AH, Spigel RH, Jowett IG, Shankar SU, Ibbitt RP (2010) Model application to assess effects of urbanisation and distributed flow controls on erosion potential and baseflow hydraulic habitat. Urban Water J 7(2):91-107. https:// doi.org/10.1080/15730620903447605

Engel B, Storm D, White M, Arnold J, Arabi M (2007) A hydrologic/water quality model Applicati1 1. JAWRA J Am Water Resources Assoc 43(5):1223-1236. https://doi.org/10.1111/j.1752-1688.2007.00105.x

Erena SH, Worku H (2018) Flood risk analysis: causes and landscape based mitigation strategies in Dire Dawa city, Ethiopia. Geoenvironment Dis 5(1). https://doi.org/10.1186/s40677-018-0110-8

Fernández DS, Lutz MA (2010) Urban flood hazard zoning in Tucumán Province, Argentina, using GIS and multicriteria decision analysis. Eng Geol 111(1-4): 90-98. https://doi.org/10.1016/j.enggeo.2009.12.006

Fewtrell TJ, Neal JC, Bates PD, Harrison PJ (2011) Geometric and structural river channel complexity and the prediction of urban inundation. Hydrol Process 25(20):3173-3186. https://doi.org/10.1002/hyp.8035

Gao Y, Yuan Y, Wang H, Zhang Z, Ye L (2018) Analysis of impacts of polders on flood processes in Qinhuai River basin, China, using the HEC-RAS model. Water Sci Technol Water Supply 18(5):1852-1860

Hammond MJ, Chen AS, Djordjević S, Butler D, Mark O (2015) Urban flood impact assessment: a state-of-the-art review. Urban Water J 12(1):14-29. https://doi. org/10.1080/1573062X.2013.857421 
Hsu MH, Chen SH, Chang TJ (2000) Inundation simulation for urban drainage basin with storm sewer system. J Hydrol 234(1-2):21-37. https://doi.org/10.1 016/S0022-1694(00)00237-7

Hung C-LJ, James LA, Hodgson ME (2018) An automated algorithm for mapping building impervious areas from airborne LiDAR point-cloud data for flood hydrology. GIScience \& Remote Sensing, pp 1-24

Jamali B, Löwe R, Bach PM, Urich C, Arnbjerg-Nielsen K, Deletic A (2018) A rapid urban flood inundation and damage assessment model. J Hydrol 564:10851098. https://doi.org/10.1016/j.jhydrol.2018.07.064

Kamali M, Delkash M, Tajrishy M (2017) Evaluation of permeable pavement responses to urban surface runoff. J Environ Manag 187:43-53. https://doi. org/10.1016/j.jenvman.2016.11.027

Kokangül A, Polat U, Dağsuyu C (2017) A new approximation for risk assessment using the AHP and fine Kinney methodologies. Saf Sci 91:24-32. https://doi. org/10.1016/j.ssci.2016.07.015

Lee S (2018) Integrated 1D/2D urban inundation modelling with refined grid and OpenMP parallelization. International conference on urban drainage modelling, pp 566-570

Li W, Chen Q, Mao J (2009) Development of 1D and 2D coupled model to simulate urban inundation: an application to Beijing Olympic Village. Chin Sci Bull 54(9):1613-1621

Lin S-S, Hsieh S-H, Kuo J-T, Liao Y-P, Chen Y-C (2006) Integrating legacy components into a software system for storm sewer simulation. Environ Model Softw 21(8):1129-1140. https://doi.org/10.1016/j.envsoft.2005.05.012

Löwe R, Urich C, Domingo NS, Mark O, Deletic A, Arnbjerg-Nielsen K (2017) Assessment of urban pluvial flood risk and efficiency of adaptation options through simulations-a new generation of urban planning tools. J Hydrol 550: 355-367. https://doi.org/10.1016/j.jhydrol.2017.05.009

Luu C, Von Meding J, Kanjanabootra S (2018) Assessing flood hazard using flood marks and analytic hierarchy process approach: a case study for the 2013 flood event in Quang Nam, Vietnam. Nat Hazards 90(3):1031-1050. https:// doi.org/10.1007/s11069-017-3083-0

Nash JE, Sutcliffe JV (1970) River flow forecasting through conceptual models part I_A discussion of principles. J Hydrol 10(3):282-290. https://doi.org/10.1 016/0022-1694(70)90255-6

Papaioannou G, Vasiliades L, Loukas A (2015) Multi-criteria analysis framework for potential flood prone areas mapping. Water Resour Manag 29(2):399-418. https://doi.org/10.1007/s11269-014-0817-6

Papaioannou G, Efstratiadis A, Vasiliades L, Loukas A, Papalexiou S, Koukouvinos A, Tsoukalas I, Kossieris P (2018) An operational method for flood directive implementation in ungauged urban areas. Hydrology 5(2):24. https://doi. org/10.3390/hydrology5020024

Phillips R, Jeswani HK, Azapagic A, Apul D (2018) Are stormwater pollution impacts significant in life cycle assessment? A new methodology for quantifying embedded urban stormwater impacts. Sci Total Environ 636:115123. https://doi.org/10.1016/j.scitotenv.2018.04.200

Pitt, R., \& Jr, G. B. (2001). Stormwater effects handbook: A toolbox for watershed managers, scientists, and engineers. https://www.taylorfrancis.com/books/ 9781420036244

Price RK, Vojinovic Z (2008) Urban flood disaster management. Urban Water J 5(3):259-276. https://doi.org/10.1080/15730620802099721

Qin H, He K, Fu G (2016) Modeling middle and final flush effects of urban runoff pollution in an urbanizing catchment. J Hydrol 534:638-647. https://doi.org/1 0.1016/j.jhydrol.2016.01.038

Radice A, Bettiga A, Figueiredo R, Molinari D (2017) On urban inundation and damage modelling. EWRA 2017, 10th World Congress on Water Resources and Environment, pp 11-17

Reuterwall L, Thorén H (2009) Identification of flood risk areas in an open stormwater system with MIKE URBAN-Senai town, Malaysia

Rossman, L. a. (2010). Storm Water Management Model User's Manual, Version 5. 0. United States Environment Protection Agency, July, 285. https://doi.org/ PNR61

Rossman, L. A. (2004). Storm water management model User's manual version 5. 0. November, 245. https://pdfs.semanticscholar.org/05ba/f15633bc5274 e809427ddc24e3dca2521d1b.pdf

Russo B, Sunyer D, Velasco M, Djordjević S (2015) Analysis of extreme flooding events through a calibrated 1D/2D coupled model: the case of Barcelona (Spain). J Hydroinf 17(3):473-491. https://doi.org/10.2166/hydro.2014.063

Saaty TL (1980) The analytic hierarchy process (New York: McGrawHill, 1980). MATH Google Scholar
Sarhadi A, Soltani S, Modarres R (2012) Probabilistic flood inundation mapping of ungauged rivers: linking GIS techniques and frequency analysis. J Hydrol 458: 68-86

Shuster WD, Bonta J, Thurston H, Warnemuende E, Smith DR (2005) Impacts of impervious surface on watershed hydrology: a review. Urban Water J 2(4): 263-275. https://doi.org/10.1080/15730620500386529

Sillanpää N, Koivusalo H (2015) Impacts of urban development on runoff event characteristics and unit hydrographs across warm and cold seasons in high latitudes. J Hydrol 521:328-340. https://doi.org/10.1016/j.jhydrol.2014.12.008

Sleiman M (2018) The impact of bridge intrusion on the Mill River: hydraulic modelling and analysis using HEC-RAS

Staff U (2008) HEC-RAS River analysis system, User's manual version 4.0. US Army Corps of Engineers, Hydrologic Engineering Center (HEC) Publication, p 733

Temprano J, Arango Ó, Cagiao J, Suárez J, Tejero I (2005) Stormwater quality calibration by SWMM: a case study in northern Spain. Water SA 32(1):55-63

Thirumurugan P, Krishnaveni M (2019) Flood hazard mapping using geospatial techniques and satellite images - a case study of coastal district of Tamil Nadu. Environ Monit Assess 191(3):193. https://doi.org/10.1007/s10661-0197327-1

Tingsanchali T (2012) Urban flood disaster management. Procedia Engineering 32:25-37. https://doi.org/10.1016/j.proeng.2012.01.1233

Tsihrintzis VA, Hamid R (1998) Runoff quality prediction from small urban catchments using SWMM. Hydrol Process 12(2):311-329. https://doi.org/10.1 002/(SICI)1099-1085(199802)12:2<311::AID-HYP579>3.0.CO;2-R

Wahren A, Feger K-H, Schwärzel K, Münch A (2009) Land-use effects on flood generation-considering soil hydraulic measurements in modelling. Adv Geosci 21:99-107. https://doi.org/10.5194/adgeo-21-99-2009

Wu J, Yang R, Song J (2018) Effectiveness of low-impact development for urban inundation risk mitigation under different scenarios: a case study in Shenzhen, China. Nat Hazards Earth Syst Sci 18(9):2525-2536. https://doi. org/10.5194/nhess-18-2525-2018

Wu X, Wang Z, Guo S, Liao W, Zeng Z, Chen X (2017) Scenario-based projections of future urban inundation within a coupled hydrodynamic model framework: a case study in Dongguan City, China. J Hydrol 547:428-442. https://doi.org/10.1016/j.jhydrol.2017.02.020

Xing W, Li P, Cao S, Gan L, Liu F, Zuo J (2016) Layout effects and optimization of runoff storage and filtration facilities based on SWMM simulation in a demonstration area. Water Sci Eng 9(2):115-124. https://doi.org/10.1016/j. wse.2016.06.007

Yu H, Huang G, Wu C (2015) Efficient finite-volume model for shallow-water flows using an implicit dual time-stepping method. J Hydraul Eng 141(6): 4015004. https://doi.org/10.1061/(ASCE)HY.1943-7900.0000998

Zhu Z, Chen Z, Chen X, He P (2016) Approach for evaluating inundation risks in urban drainage systems. Sci Total Environ 553:1-12. https://doi.org/10.1016/j. scitotenv.2016.02.025

Zin WW, Kawasaki A, Takeuchi W, San ZMLT, Htun KZ, Aye TH, Win S (2018) Flood Hazard assessment of Bago River basin, Myanmar. J Dis Res 13(1):15

Zoppou C (2001) Review of urban storm water models. Environ Model Softw 16(3):195-231. https://doi.org/10.1016/S1364-8152(00)00084-0

\section{Publisher's Note}

Springer Nature remains neutral with regard to jurisdictional claims in published maps and institutional affiliations.

\section{Submit your manuscript to a SpringerOpen ${ }^{\circ}$ journal and benefit from:}

- Convenient online submission

- Rigorous peer review

- Open access: articles freely available online

High visibility within the field

- Retaining the copyright to your article

Submit your next manuscript at $\boldsymbol{\sim}$ springeropen.com 